\title{
Frequent neck massage leading to bilateral anterior cerebral artery infarction
}

\author{
Jaslovleen Kaur, Monika Singla, Gursimran Singh, Gagandeep Singh
}

Department of Neurology, Dayanand Medical College \& Hospital, Ludhiana, Punjab, India

Correspondence to Dr Jaslovleen Kaur, jaslovleen@gmail.com

Accepted 25 October 2017

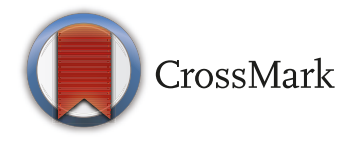

\footnotetext{
To cite: Kaur J, Singla M, Singh G, et al. BMJ Case Rep Published Online First: [please include Day Month Year]. doi:10.1136/bcr-2017222169
}

\section{DESCRIPTION}

The anterior cerebral artery (ACA) is a major vessel responsible for the blood supply to the interhemispheric regions. Infarction of the ACA territory accounts for only $0.3 \%$ to $4.4 \%$ of cerebral infarctions reported. ${ }^{1}$ The usual causes are aneurysmal rupture of the anterior communicating artery or thrombosis of the precommunal anterior cerebral artery. ${ }^{2}$ We are describing here a patient with bilateral ACA infarction due to dual pathology and frequent neck massage being the cause of this young stroke.

A 45-year-old man was admitted with sudden onset aphasia and weakness of both lower limbs with bowel-bladder incontinence. There was no history of loss of consciousness, headache, nausea or vomiting and convulsions. He had no significant medical history and no vascular risk factors. There is history of frequent neck massages from a chiropractor for relaxation purposes with visits amounting to two to four per week. There is no history of neck pain or any transient neurological deficit signs. On admission, he was mute and abulic with receptive aphasia and bilateral lower limb weakness. The frontal release signs including snout reflex and grasp reflex were present, along with altered behaviour and personality, suggesting

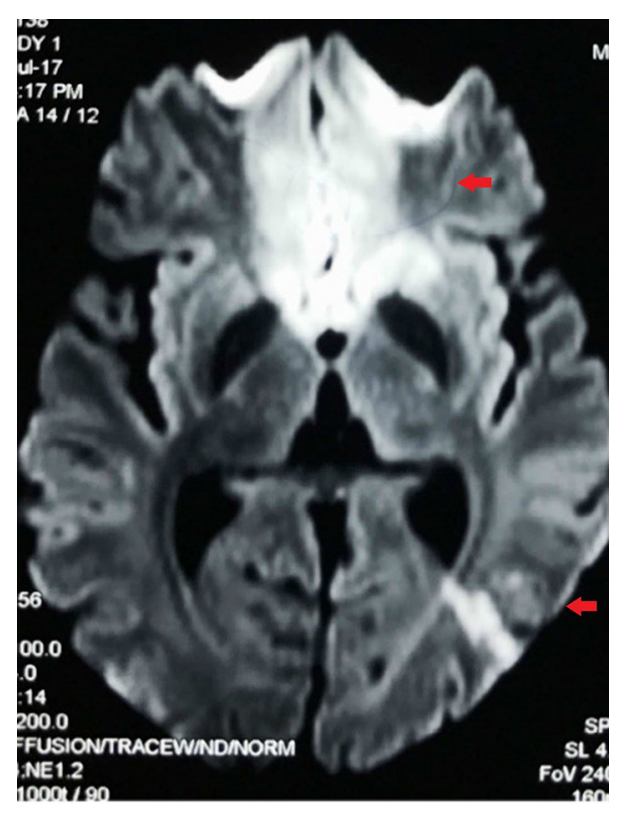

Figure 1 MRI brain diffusion-weighted image. Areas of diffusion restriction (red arrows) in the bifrontal area and left parieto-occipital area suggest hyperacute infarcts in bilateral ACA territory and left middle cerebral arteryposterior cerebral artery watershed territory.

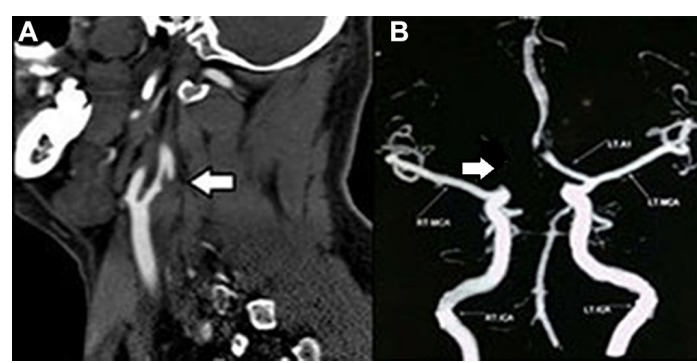

Figure 2 (A) CT angiography. A narrowed eccentric lumen surrounded by a crescent-shaped mural thrombus can be noted in the posterior wall of the extracranial part of the left internal carotid artery (white arrow) distal to its origin from the common carotid artery, suggesting left internal carotid artery dissection. (B) The precommunal segment of the right anterior cerebral artery is not well visualised-hypoplastic as shown in the image (white arrow).

frontal lobe disruption. Routine full blood count and biochemical analysis were normal. MRI brain showed bilateral ACA infarction with left middle cerebral artery-posterior cerebral artery watershed infarct. It also suggested thrombosis in bilateral ACA (figure 1). Further CT angiogram revealed non-visualisation of precommunal right ACA (hypoplastic) and internal carotid artery (ICA) dissection in its cervical part (figure 2). Patient was started with antiplatelet and low molecular weight heparin, which was later converted to oral anticoagulant, warfarin. Patient is on regular follow-up and improving with neurorehabilitation department services. A dual pathology of bilateral ACA infarction was suggested in our case due to bilateral ACA thrombosis and intracranial ICA dissection. Cervical spine manipulation in the form of neck massage or trivial neck trauma is a known potential mechanical trigger for cervical artery dissection. Arterial dissection involves a tear in the artery's

Learning points

- Bilateral anterior cerebral artery (ACA) infarction is still rare to be reported, but because of advanced neuroimaging techniques, anomalies of the ACA vasculature are now reported more frequently in such cases.

- Along with usual causes of anomalous vasculature in such infarcts, we should always rule out possibilities of other pathophysiology including thrombosis and of course dissection as in our case. 
lining and formation of an intimal flap, which allows penetration of blood between the vessel layers, resulting in arterial narrowing or even complete obstruction of the lumen, leading to ischaemic neurological signs. In our subject, due to hypoplastic right ACA, the left ICA dissection is causing bilateral ACA infarcts and left MCA watershed infarcts. And in view of the repeated cervical spine manipulation, we consider the chiropractic neck massage to be the trigger factor for this intracranial ICA dissection-induced anterior circulation infarcts.

Contributors JK: collection of data, conception and research. MS: structuring of the case. GuS: imaging collection. GaS: analysis and interpretation of data.
Competing interests None declared.

Patient consent Guardian consent obtained.

Provenance and peer review Not commissioned; externally peer reviewed.

(C) BMJ Publishing Group Ltd (unless otherwise stated in the text of the article) 2017. All rights reserved. No commercial use is permitted unless otherwise expressly granted.

\section{REFERENCES}

1 Gacs G, Fox AJ, Barnett HJ, et al. Occurrence and mechanisms of occlusion of the anterior cerebral artery. Stroke 1983;14:952-9.

2 Ross Russell RW. Vascular disease of the central nervous system. Edinburgh, Scotland: Churchill Livingstone, Inc, 1983:170-3.

Copyright 2017 BMJ Publishing Group. All rights reserved. For permission to reuse any of this content visit

http://group.bmj.com/group/rights-licensing/permissions.

BMJ Case Report Fellows may re-use this article for personal use and teaching without any further permission.

Become a Fellow of BMJ Case Reports today and you can:

- Submit as many cases as you like

- Enjoy fast sympathetic peer review and rapid publication of accepted articles

Access all the published articles

Re-use any of the published material for personal use and teaching without further permission

For information on Institutional Fellowships contact consortiasales@bmjgroup.com

Visit casereports.bmj.com for more articles like this and to become a Fellow 